\title{
CONTRIBUTORS
}

\section{Lotte Bailyn}

Sloan School of Management

Massachusetts Institute of Technology

50 Memorial Drive

Cambridge, Mass. 02139

\section{Stephen R. Barley}

Industrial Engineering and Engineering Management

340 Terman Hall

Stanford University

Stanford, Calif. 94305

\section{Louis L. Bucciarelli}

School of Engineering

3-282

Massachusetts Institute of Technology 77 Massachusetts Avenue

Cambridge, Mass. 02139

\section{Larry Carbone}

School of Veterinary Medicine

Cornell University

Ithaca, N.Y. 14853

\section{H. M. Collins}

Centre for the Study of Knowledge, Expertise and Science

Dept. of Sociology and Social Policy

University of Southampton

Southampton SO17 1BS

U.K.

\section{Sean Creighton}

Department of Sociology

Ballantine Hall, Room 751

Indiana University

Bloomington, Ind. 47401

\section{Randy Hodson}

Department of Sociology

Ballantine Hall, Room 751

Indiana University

Bloomington, Ind. 47401

\section{Jeffrey Keefe}

School of Management and Labor

Relations

Rutgers University

P.O. Box 231 Ryders Lane

New Brunswick, N.J. 08903 


\section{Sarah Kuhn}

Policy and Planning Department

College of Management

University of Massachusetts-Lowell

One University Avenue

Lowell, Mass. 01853

\section{Bonalyn J. Nelsen}

Johnson Graduate School of Management

Cornell University

Ithaca, N.Y. 14853

Julian E. Orr

Xerox PARC

3333 Coyote Hill Road

Palo Alto, Calif. 94304

\section{Brian T. Pentland}

School of Labor and Industrial Relations

412 South Kedsie Hall

Michigan State University

East Lansing, Mich. 48824-1032

\section{Leslie Perlow}

University of Michigan Business School 701 Tappan Street

Ann Arbor, Mich. 48109-1234

\section{Trevor Pinch}

Science and Technology Studies

622 Clark Hall

Cornell University

Ithaca, N.Y. 14853

\section{Denise Potosky}

Graduate Program in Management The Pennsylvania State University Great Valley Campus

30 E. Swedesford Road

Malvern, Penn. 19355

\section{Mario Scarselletta}

Corning Inc.

Science Products Division

Corning, N.Y. 14831

\section{Peter Whalley}

Department of Sociology and Anthropology

Loyola University Chicago

Lake Shore Campus

6525 North Sheridan Road

Chicago, Ill. 60626

\section{Stacia E. Zabusky}

Associate in Research

Institute of European Studies

Cornell University

Ithaca, N.Y. 14853 
BETWEEN
CRAFT
AND
SCIENCE 
